\title{
An epidemiological study of blood pressure and metabolic phenotypes in relation to the $\mathbf{G} \boldsymbol{\beta}_{\mathbf{3}} \mathbf{C 8 2 5 T}$ polymorphism Eva Brand ${ }^{a}$, Ji-Guang Wang ${ }^{b}$, Stefan-Martin Herrmann ${ }^{c, d}$ and Jan A. Staessen ${ }^{b}$
}

\begin{abstract}
Background The $825 T$ allele of the G-protein $\beta_{3}$-subunit gene is associated with increased intracellular signalling and adipogenesis in experimental studies. We studied the C825T polymorphism in relation to blood pressure, obesity and intermediate phenotypes in a Caucasian population.

Methods We genotyped 737 men and 775 women (participation rate, 64.3\%) enrolled in a Belgian population study. Dichotomous phenotypes were tested for association with the C825T polymorphism by Fisher's exact test and multiple logistic regression. For continuous traits, we used analysis of covariance and generalized estimating equations.
\end{abstract}

Results The $T$ allele (39.7 versus $29.1 \%$ ) and $T T$ genotype (16.1 versus $7.7 \%$ ) were more prevalent in obese men than in non-obese men $(P \leqslant 0.01)$. $T T$ homozygous men, compared with $C$ allele carriers, had higher daytime ambulatory blood pressure (mean systolic/diastolic differences, $3.6 / 2.5 \mathrm{mmHg} ; P \leqslant 0.02$ ), higher body weight $(2.7 \mathrm{~kg}, P=0.04)$, greater risk of obesity (risk ratio, 1.90; $P=0.005)$, increased triceps skinfold thickness $(2.3 \mathrm{~mm}$, $P=0.007)$, higher serum insulin concentration $(4.1 \mathrm{mU} /$, $P=0.006)$, more insulin resistance $(P=0.01)$, and increased erythrocyte count $\left(0.11 \times 10^{12}\right.$ cells $\left./ \mathrm{l}, P=0.04\right)$ and haematocrit $(0.9 \%, P=0.02)$. In women, haematocrit and erythrocyte count were also higher $(P \leqslant 0.03)$ in $T$ allele carriers, but other phenotypes were not correlated with the C825T polymorphism.

Conclusion Male and female carriers of the $T$ allele at position 825 of the G-protein $\beta_{3}$-subunit gene have a slightly higher haematocrit and erythrocyte count. Male $T T$ homozygotes have a higher blood pressure and are more obese and insulin-resistant than $C$ allele carriers. We speculate that the higher blood pressure in $T T$ homozygous men might arise via a metabolic pathway characterized by obesity and insulin resistance as well as via increased peripheral resistance secondary to the higher haematocrit. J Hypertens 21:729-737 @ 2003 Lippincott Williams \& Wilkins.

Journal of Hypertension 2003, 21:729-737

Keywords: blood pressure, gender, genes, G-protein, haematocrit, insulin resistance, obesity

aDepartment of Endocrinology and Nephrology and ' Department of Clinical Pharmacology, Benjamin Franklin Medical Centre, Freie Universität Berlin, Berlin,

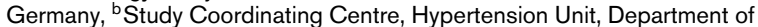
Molecular and Cardiovascular Research, Katholieke Universiteit Leuven, Leuven, Belgium and ${ }^{\mathrm{d}}$ Department of Pharmacology of Natural Products and Clinical Pharmacology, University of Ulm, Ulm, Germany.

Sponsorship: The FLEMENGHO Study was supported by research grants G.0174.97 and G.0291.98 from the Fonds voor Wetenschappelijk Onderzoek Vlaanderen (Brussels, Belgium) and a special research grant from the Katholieke Universiteit Leuven (Onderzoekstoelage OT99/28). Nuclear families were recruited in the framework of the European Project on Genes in Hypertension, which is supported by the European Union (contract numbers IC15-CT98-0329EPOGH and QLG1-CT-2000-01137-EURNETGEN). The genetic laboratory was financed in part by a research grant from the Universitätsklinikum Benjamin Franklin, Berlin, Germany (FSP-EB 1999/2000). J.-G.W. was supported by the bilateral scientific collaboration between the People's Republic of China and Flanders, Belgium (BIL 02/10). S.-M.H. received grants from the Deutsche Forschungsgemeinschaft (Graduierten-Kolleg 426/2-00, Molekularbiologische Grundlagen der Therapie and Graduierten-Kolleg 754, Myokardiale

Genexpression und Funktion, Myokardhypertrophie).

Correspondence and requests for reprints to Jan A. Staessen, Studiecoördinatiecentrum, Laboratorium Hypertensie, Campus Gasthuisberg, Herestraat 49, B-3000 Leuven, Belgium.

Tel: +32 1634 7104; fax: +32 16347106 ;

e-mail: jan.staessen@med.kuleuven.ac.be

Received 19 August 2002 Revised 28 November 2002 Accepted 13 January 2003

See editorial commentary page 683

\section{Introduction}

Guanine nucleotide regulatory proteins (G-proteins) are part of the intracellular signalling cascades [1]. Their activation is the principal mechanism through which stimulated heptahelical receptors generate changes in intracellular function [1]. Siffert and coworkers identified a common $C 825 T$ polymorphism in exon 10 of the $\beta_{3}$ subunit of the heterotrimeric G-protein [2]. The $825 T$ mutant is associated with a splice variant, which shortens the protein by 41 amino acids and produces a gain of function [2]. Increased signalling by G-proteins stimu- lates adipogenesis [3] and may lead to obesity [4]. In addition, C825T is a candidate polymorphism for hypertension, because the mutation entails stimulation of the ubiquitously expressed $\mathrm{Na}^{+} / \mathrm{H}^{+}$exchanger [5]. At the kidney level, this may increase $\mathrm{Na}^{+}$re-absorption and cause chronic volume expansion [6]. Prevention of intracellular acidosis may also lead to proliferation of vascular smooth muscle cells, vascular remodelling and increased peripheral arterial resistance [6]. However, published reports on the association between hypertension and the $825 T$ mutation produced inconsistent results [2,7-9]. 
There is growing awareness that complex age-related disorders, such as hypertension, cannot be studied from an exclusive genocentric point of view, but only within their epidemiological context [10]. Statistical analyses should account for factors, such as gender, age, lifestyle, use of medications, and circadian variability. While allowing for these influences we studied, in the Flemish Study on Environment, Genes and Health Outcomes (FLEMENGHO) [11], the G-protein $\beta_{3}$-subunit C825T polymorphism in relation to blood pressure, obesity and intermediate phenotypes selected because they may be affected by the variant signalling protein.

\section{Methods}

\section{Study population}

The Ethics Committee of the University of Leuven approved the protocol of the FLEMENGHO study. From August 1985 until November 1990, a random sample of the households living in a geographically defined area of Northern Belgium [11] was investigated with the aim of recruiting an equal number of participants in each of six subgroups by sex and age (2039 years, $40-59$ years, and $\geqslant 60$ years). All household members with a minimum age of 20 years were invited to take part until the quota of their sex-age group had been fulfilled. To further study the role of genetic factors, from June 1996 until January 1998, nuclear families including children who were at least 10 years old, were recruited using the former participants (1985-1990) as index persons [11]. In 1998 and 1999, all previously enrolled participants were invited to donate a blood sample for DNA extraction.

The study population included 2064 persons [11]. The participation rate among the subjects contacted was 64.3\%. The blood pressure of 24 participants was not measured. In 1998-1999, blood for DNA extraction could not be obtained from 403 former participants, because they did not consent $(n=161)$ or because they had died $(n=180)$, were terminally ill $(n=28)$, or had moved out of the area $(n=34)$. Because of delays between field and laboratory work or insufficient DNA amplification, 125 subjects were not genotyped. Thus, we included 1512 subjects in the present analysis.

\section{Measurement of phenotypes}

Study nurses followed the guidelines of the British Hypertension Society to measure the participants' sitting blood pressure five times consecutively at each of two home visits 4-6 weeks apart. For analysis, these 10 blood pressure readings were averaged. Hypertension was diagnosed if the mean was at least $140 \mathrm{mmHg}$ systolic or $90 \mathrm{mmHg}$ diastolic, or when patients were on antihypertensive medications. The average daytime blood pressure was determined from unedited ambulatory recordings with weights according to the time elapsed between successful readings. Vali- dated oscillometric SpaceLabs 90202 or 90207 monitors (Redmond, Washington, USA) were programmed to obtain measurements at 20 -min intervals for at least $12 \mathrm{~h}$ between 0800 and $2200 \mathrm{~h}$. For both conventional and ambulatory blood pressure measurement, standard cuffs had a $12 \times 24 \mathrm{~cm}$ inflatable portion, but if the upper arm girth exceeded $31 \mathrm{~cm}$ then cuffs with a $15 \times 35 \mathrm{~cm}$ bladder were employed.

Weight and height were measured without shoes with the subjects wearing light indoor clothing. Subjects were classified as normal, overweight or obese if their body mass index was $<25.0,25.0-29.9$ or $\geqslant 30.0 \mathrm{~kg} /$ $\mathrm{m}^{2}$, respectively. Triceps skinfold was determined at the left arm using a Harpender caliper providing a constant pressure of $0.01 \mathrm{~kg} / \mathrm{mm}^{2}( \pm 10 \%)$ at all openings of the $90 \mathrm{~mm}^{2}$ anvils. We administered a validated [11] questionnaire to collect information about the subjects' medical history, use of medications, smoking habits, intake of alcohol, physical activity, and menstrual status of women. From the questionnaire data and body weight, we estimated energy expenditure due to physical activity.

In the interval between the two home visits, the participants collected a 24-h urine sample in a wideneck plastic container for measurement of sodium, potassium and creatinine. A venous blood sample for the determination of plasma renin activity was obtained usually within 2 weeks of the urine collection. As measure of insulin resistance, the homeostasis model assessment index (HOMA) was calculated from blood glucose and serum insulin concentrations determined after an overnight fast [12]. Erythrocytosis was an erythrocyte count of $\geqslant 5.5 \times 10^{12}$ cells/ 1 in men and $\geqslant 5.0 \times 10^{12}$ cells/ 1 in women. The diagnosis of diabetes mellitus relied on the medical history confirmed by each subject's doctor, on blood glucose concentrations of $\geqslant 6.1 \mathrm{mmol} / \mathrm{l}$ or $\geqslant 10.0 \mathrm{mmol} / \mathrm{l}$ in fasting and non-fasting conditions, respectively, or on the observation of glucosuria $(>5.5 \mathrm{mmol} / \mathrm{l})$ by dipstick test on a fresh urine sample.

\section{Determination of the genotype}

Genomic DNA was extracted from white blood cells. From the published DNA sequence of the G-protein $\beta_{3}$-subunit gene [13], we amplified a 268 base pair fragment incorporating the polymorphic site with use of two primers as described by Siffert and coworkers [2]. We have previously published the technical procedures, which we implemented for DNA amplification and subsequent measurement of the genotypes by allelespecific hybridization [8].

\section{Statistical methods}

For statistical analysis, we used SAS version 8.1 (SAS Institute, Cary, North Carolina, USA). Continuous 
measurements with a skewed distribution were normalized by logarithmic transformation and represented by the geometric mean and its $95 \%$ confidence interval (95\% CI). Proportions were compared by Fisher's exact test. In each gender separately, we first searched for possible confounders using stepwise multiple regression with the $P$ value for co-variables to enter and stay in the model set at 0.15 . We used multiple logistic regression to test the associations between dichotomous phenotypes and genotypes while controlling for covariables. In logistic regression, genotypes were represented by dummy variables defined according to the deviation from the mean coding approach, which does not imply any genetic hypothesis [14]. Continuous traits adjusted for co-variables were first analysed by analysis of covariance. Because in men genetic heterogeneity among pathophysiologically related phenotypes consistently suggested a recessive pattern, we subsequently compared TT homozygotes only with $C$ allele carriers, using the least-square mean option of the PROC GLM procedure. Finally, we repeated our analyses using generalized estimating equations $[15,16]$ to allow for the non-independence of the observations among related subjects. In the PROC GENMOD procedure of the SAS package, we defined the intrafamilial correlation matrices based on our own data and we adjusted for the same co-variables as in the analysis of co-variance.

\section{Results}

\section{Characteristics of participants}

The 1512 participants included 737 men and 775 women (Table 1). One hundred and forty-five (9.6\%) participants were younger than 20 years, 489 were aged

Table 1 Characteristics of participants

\begin{tabular}{lcc}
\hline Characteristics & Men $(n=737)$ & Women $(n=775)$ \\
\hline Clinical measurements & & \\
Body height $(\mathrm{cm})$ & $173.7 \pm 7.9$ & $161.5 \pm 6.9$ \\
Body weight $(\mathrm{kg})$ & $77.0 \pm 13.0$ & $65.6 \pm 13.0$ \\
Systolic pressure $(\mathrm{mmHg})^{*}$ & $125.5 \pm 15.2$ & $120.9 \pm 16.9$ \\
Diastolic pressure $(\mathrm{mmHg})^{*}$ & $77.0 \pm 10.5$ & $74.2 \pm 10.3$ \\
Pulse rate (beats/min) & $67.9 \pm 9.6$ & $71.1 \pm 10.0$ \\
Physical activity (kcal/day) ${ }^{\dagger}$ & $1.42(1.34-1.51)$ & $1.29(1.22-1.37)$ \\
Daytime ambulatory measurements & & \\
Systolic pressure (mmHg) & $126.5 \pm 10.5$ & $122.1 \pm 10.9$ \\
Diastolic pressure (mmHg) & $77.0 \pm 8.4$ & $74.7 \pm 7.6$ \\
Pulse rate (beats/min) & $75.2 \pm 11.0$ & $80.7 \pm 10.4$ \\
Urinary measurements $\$$ & & \\
Volume (I/day) & $1.49 \pm 0.60$ & $1.56 \pm 0.68$ \\
Creatinine (mmol/day) & $13.9 \pm 3.7$ & $9.4 \pm 2.4$ \\
Sodium (mmol/day) & $201 \pm 70$ & $162 \pm 58$ \\
Potassium (mmol/day) & $78 \pm 30$ & $64 \pm 23$ \\
Number (\%) on treatment & & \\
Antihypertensive drugs & $71(9.6)$ & $102(13.2)$ \\
$\beta$-Blockers & $42(5.7)$ & $58(7.5)$ \\
Diuretics & $25(3.4)$ & $57(7.4)$ \\
\hline
\end{tabular}

Unless indicated otherwise, values are means \pm standard deviation. ${ }^{*}$ Individual values are means of 10 readings, five at each of two separate home visits.

Geometric mean with $95 \% \mathrm{Cl}$ for 644 men and 684 women. Means of daytime $(1000-2000 \mathrm{~h})$ measurements in 716 men and 753 women. ${ }^{\S} 720$ men and 762 women collected a 24 -h urine specimen.
$20-39$ years $(32.3 \%), 618(40.9 \%)$ were aged $40-59$ years, and $260(17.2 \%)$ were 60 years or older. Men and women had similar age distributions with medians (interquartile range) of 42.9 years $(32.1-55.8$ years) and 43.0 years $(32.9-56.0$ years $)$, respectively $(P=0.82$ for gender difference). The study sample consisted of 762 unrelated individuals including 35 spouse pairs without offspring, and of 203 families with one to seven children (327 parents, 423 offspring; median number of offspring per family, 2).

Mean (standard deviation) body mass index was $25.5 \mathrm{~kg} / \mathrm{m}^{2}\left(3.9 \mathrm{~kg} / \mathrm{m}^{2}\right)$ in men and $25.2 \mathrm{~kg} / \mathrm{m}^{2}(5.1 \mathrm{~kg} /$ $\left.\mathrm{m}^{2}\right)$ in women $(P=0.23)$. Body mass index did not differ among smokers and non-smokers (25.3 versus $25.6 \mathrm{~kg} / \mathrm{m}^{2}, P=0.26$ ), but was higher in subjects reporting alcohol consumption $\left(26.2\right.$ versus $25.1 \mathrm{~kg} / \mathrm{m}^{2}, P=$ 0.0003 ) or intake of $\beta$-blockers (27.6 versus $25.4 \mathrm{~kg} / \mathrm{m}^{2}$, $P=0.0003)$. Hypertension $(n=352,23.3 \%)$, obesity $(n=193,12.8 \%)$, diabetes mellitus $(n=43,2.9 \%)$ and erythrocytosis $(n=86,5.8 \%)$ were equally prevalent $(P>0.28)$ among men and women. Two hundred and thirty-two men $(31.5 \%)$ were current smokers and 245 (33.2\%) reported intake of alcohol. Among women, these numbers were $215(27.7 \%)$ and 88 (11.4\%), respectively. One hundred and forty-seven women $(19.0 \%)$ used oral contraceptives and $14(1.8 \%)$ took hormonal replacement therapy.

\section{Genotype and allele frequencies}

The C825T genotype frequencies were $47.3 \%(n=715)$ for $C G, 43.8 \%(n=662)$ for $C T$, and $8.9 \%(n=135)$ for $T T$, and did not deviate from Hardy-Weinberg equilibrium $(P=0.30)$. The $C$ and $T$ allele frequencies were 69.2 and $30.8 \%$. According to Fisher's exact test, genotype and allele frequencies did not differ according to the presence or absence of hypertension (Table 2). These findings remained unaltered if 197 untreated white-coat hypertensive patients with normal daytime systolic and diastolic pressures $(<135 /<85 \mathrm{mmHg})$ were excluded from analysis. In men, but not in women, the frequencies of the $T$ allele and the $T T$ genotype were significantly higher in obese subjects than in the other participants $(P \leqslant 0.01$; Table 2$)$.

\section{Association analysis in men}

Co-variables identified by stepwise regression analysis are presented in Table 3. Compared with the overall risk in men, TT homozygous men had a $1.90(95 \% \mathrm{CI}$, $1.21-2.98 ; P=0.005$ ) higher risk of obesity (Fig. 1) and a $1.81(95 \%$ CI, $1.03-3.17 ; P=0.04)$ higher risk of erythrocytosis (Fig. 2). Conversely, men with the $C C$ genotype had a lower risk of obesity [risk ratio, 0.61 (95\% CI, 0.43-0.86); $P=0.004$; Fig. 1].

In unadjusted analyses, the analysis of variance $P$ values for the continuous phenotypes presented in 
Table 2 Genotype and allele frequencies by sex and classes of blood pressure and body mass index

\begin{tabular}{|c|c|c|c|c|c|c|c|}
\hline \multirow[b]{2}{*}{ Characteristic } & \multicolumn{3}{|c|}{ Number of subjects (\%) with genotype } & \multirow[b]{2}{*}{$P^{\dagger}$} & \multicolumn{2}{|c|}{ Number of alleles (\%) } & \multirow[b]{2}{*}{$P^{\dagger}$} \\
\hline & CC & $C T$ & $T T$ & & C & $T$ & \\
\hline \multicolumn{8}{|l|}{$\operatorname{Men}(n=737)$} \\
\hline Normotension* & $256(45.6)$ & $261(46.5)$ & $44(7.9)$ & \multirow{4}{*}{0.17} & 773 (68.9) & $349(31.1)$ & \multirow{4}{*}{0.47} \\
\hline Hypertension* & $91(51.7)$ & 68 (38.6) & $17(9.7)$ & & $250(71.0)$ & $102(29.0)$ & \\
\hline Normal weight & $162(49.5)$ & $140(42.8)$ & $25(7.7)$ & & $464(70.9)$ & $190(29.1)$ & \\
\hline Overweight & $153(47.4)$ & $148(45.8)$ & $22(6.8)$ & & $454(70.3)$ & $192(29.7)$ & \\
\hline Obese & $32(36.8)$ & $41(47.1)$ & $14(16.1)$ & 0.01 & $105(60.3)$ & 69 (39.7) & 0.007 \\
\hline \multicolumn{8}{|l|}{ Women $(n=775)$} \\
\hline Normotension & $286(47.8)$ & $250(41.7)$ & $63(10.5)$ & \multirow{4}{*}{0.16} & $822(68.6)$ & $376(31.4)$ & \multirow{4}{*}{0.60} \\
\hline Hypertension & $82(46.6)$ & $83(47.2)$ & $11(6.2)$ & & $247(70.2)$ & $105(29.8)$ & \\
\hline Normal weight & $204(47.8)$ & $181(42.4)$ & $42(9.8)$ & & $589(69.0)$ & $265(31.0)$ & \\
\hline Overweight & $116(47.9)$ & $103(42.6)$ & $23(9.5)$ & & $335(69.2)$ & $149(30.8)$ & \\
\hline Obese & $48(45.3)$ & $49(46.2)$ & $9(8.5)$ & 0.80 & 145 (68.4) & $67(31.6)$ & 0.87 \\
\hline
\end{tabular}

*Classification based on the mean of 10 blood pressure measurements at home and World Health Organization/International Society of Hypertension limits. ${ }^{\dagger}$ Fisher's exact test was used to compare hypertensive with normotensive subjects as well as obese participants (body mass index $\geqslant 30.0 \mathrm{~kg} / \mathrm{m}^{2}$ ) with those who had normal body weight $\left(<25.0 \mathrm{~kg} / \mathrm{m}^{2}\right)$ or who were overweight $\left(25.0-29.9 \mathrm{~kg} / \mathrm{m}^{2}\right)$.

Table 3 Co-variables selected in stepwise regression

\begin{tabular}{|c|c|c|}
\hline Phenotypes & Co-variables in men and women & Additional co-variables in women \\
\hline $\begin{array}{l}\text { Blood pressure at home and } \\
\text { daytime ambulatory pressure }\end{array}$ & $\begin{array}{l}\text { Age, age }{ }^{2} \text {, smoking, alcohol intake, } \\
\text { and antihypertensive treatment }\end{array}$ & $\begin{array}{l}\text { Menopause, use of oral } \\
\text { contraceptives }\end{array}$ \\
\hline $\begin{array}{l}\text { Body weight, body mass index and } \\
\text { triceps skinfold thickness }\end{array}$ & $\begin{array}{l}\text { Age, age }{ }^{2} \text {, height (not considered } \\
\text { for body mass index), smoking, } \\
\text { alcohol intake, and use of } \beta \text { - } \\
\text { blockers, diuretics or both }\end{array}$ & Use of oral contraceptives \\
\hline Plasma renin activity & $\begin{array}{l}\text { Age, body mass index, smoking, } \\
\text { alcohol consumption, use of } \beta- \\
\text { blockers and diuretics, time of day } \\
\text { of blood sampling, urinary } \mathrm{Na}^{+} / \mathrm{K}^{+} \\
\text {ratio }\end{array}$ & Use of oral contraceptives \\
\hline $\begin{array}{l}\text { Erythrocyte count, haematocrit, } \\
\text { plasma insulin, and insulin } \\
\text { resistance }\end{array}$ & $\begin{array}{l}\text { Age, body mass index, smoking, } \\
\text { alcohol consumption, use of } \beta- \\
\text { blockers and diuretics }\end{array}$ & Use of oral contraceptives \\
\hline
\end{tabular}

Smoking, alcohol intake, menopause and use of medications were coded 0 or 1 for condition absent or present.

Table 4 ranged from 0.002 for plasma insulin concentration or insulin resistance up to 0.11 for systolic blood pressure at home. With full adjustments applied for the co-variables presented in Table 3 , the analysis of variance $P$ values in Table 4 were $\leqslant 0.06$ except for systolic pressure measured at home $(P=0.12)$. Because in men genetic heterogeneity among pathophysiologically related phenotypes consistently suggested a recessive effect of the $T$ allele, we subsequently compared TT homozygotes with $C$ allele carriers. TT homozygous men had elevated systolic (129.8 versus $126.2 \mathrm{mmHg}$, $P=0.009)$ and diastolic $(79.3$ versus $76.8 \mathrm{mmHg}$, $P=0.02$ ) daytime ambulatory blood pressures, increased body weight ( 79.5 versus $76.8 \mathrm{~kg}, P=0.04$ ) and triceps skinfold thickness $(14.7$ versus $12.4 \mathrm{~mm}$, $P=0.007)$, higher serum insulin levels (15.4 versus $11.3 \mathrm{mU} / \mathrm{l}, P=0.006$ ), more insulin resistance (HOMA index, 2.23 versus $1.66 ; P=0.01)$, and increased erythrocyte count $\left(4.99 \times 10^{12}\right.$ versus $4.88 \times 10^{12}$ cells $/$, $P=0.04)$ and haematocrit $(45.8$ versus $44.9 \%, P=$ $0.02)$. On the other hand, $T T$ homozygotes compared with $C$ allele carriers, had similar fasting blood glucose (5.1 versus $5.0 \mathrm{mmol} / \mathrm{l}, P=0.57$ ), plasma renin activity ( 0.49 versus $0.43 \mathrm{ng} / \mathrm{l}$ per s; $P=0.21)$, and urinary $\mathrm{Na}^{+} /$ $\mathrm{K}^{+}$ratio (2.90 versus $2.77, P=0.37$ ).

Using a multiple regression approach, we explored to what extent body mass index, haematocrit and C825T genotype explained the variance in daytime blood pressure. After adjustment for the co-variables presented in Table 3 as well as for reciprocal effects, body mass index, haematocrit and C825T genotype, respectively, explained $3.5 \% \quad(P<0.0001), 0.8 \% \quad(P=0.02)$ and $0.6 \%(P=0.04)$ of systolic pressure (model $R^{2}=$ $0.086)$ and $1.5 \%(P=0.001), 0.5 \%(P=0.06)$ and $0.6 \%$ $(P=0.04)$ of diastolic pressure (model $\left.R^{2}=0.198\right)$.

\section{Association analysis in women}

In women (Table 5), both before and after adjustment for the co-variables presented in Table 3 , haematocrit $(P=0.03)$ and erythrocyte count $(P<0.001)$ were higher in $T$ allele carriers, but none of the other 
Fig. 1

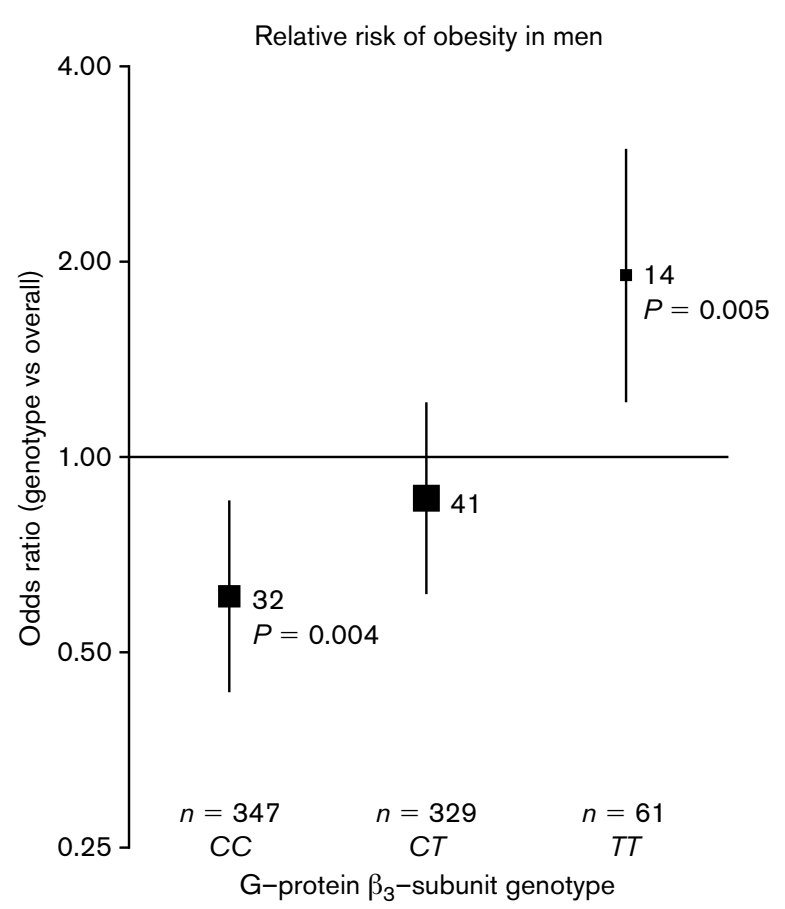

Relative risk of obesity associated with the G-protein $\beta_{3}$-subunit genotype in men. The risk of obesity (body mass index $\geqslant 30 \mathrm{~kg} / \mathrm{m}^{2}$ ) is expressed relative to that in all men and is adjusted for age, age ${ }^{2}$, smoking, alcohol intake, and the use of $\beta$-blockers and diuretics. Vertical lines denote 95\% confidence intervals. For each genotype, the number of subjects is given. The size of the squares is proportional to the number of obese subjects given alongside the squares.

phenotypes was correlated with the $C 825 T$ polymorphism. In particular, body mass index and daytime blood pressure were neither associated with the $T$ allele in all women (Table 5) nor in subgroups defined on the basis of median age $(P>0.27)$, and/or multiparity $(P>0.20)$.
Fig. 2

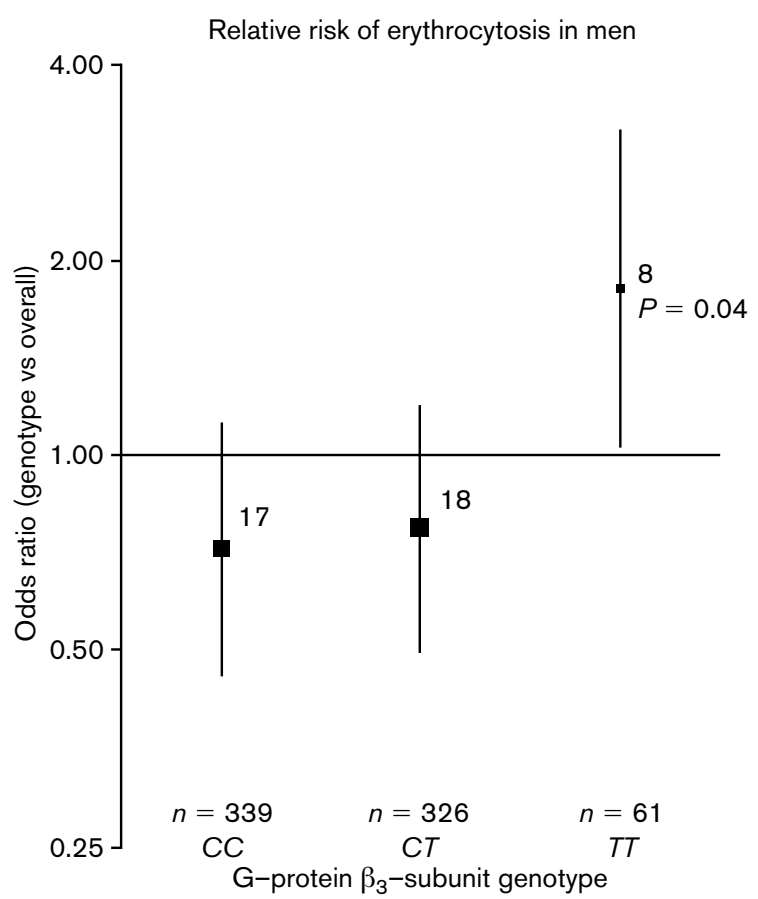

Relative risk of erythrocytosis associated with the G-protein $\beta_{3}$-subunit genotype in men. The risk of erythrocytosis (red blood cell count $\geqslant 5.5 \times 10^{12}$ cells/l) is adjusted for age, body mass index, smoking, alcohol intake and the use of $\beta$-blockers and diuretics. Further explanation as in Fig. 1.

\section{Sensitivity analyses}

In men (Table 4) as well as in women (Table 5), the findings obtained by analysis of co-variance remained unaltered after exclusion of subjects on antihypertensive treatment or after additional forced adjustments for physical activity or the presence of diabetes mellitus. In addition, we also repeated our analyses with similar

Table 4 Adjusted phenotypes by G-protein $\beta_{3}$-subunit genotype in men

\begin{tabular}{|c|c|c|c|c|c|c|c|c|}
\hline & \multirow{2}{*}{\multicolumn{6}{|c|}{ Adjusted G-protein $\beta_{3}$-subunit genotypes }} & \multirow{3}{*}{\multicolumn{2}{|c|}{$\begin{array}{c}P \text { values* } \\
\begin{array}{c}\text { Level of } \\
\text { adjustment }\end{array}\end{array}$}} \\
\hline & & & & & & & & \\
\hline & \multicolumn{2}{|r|}{$\mathrm{CC}$} & \multicolumn{2}{|r|}{$C T$} & \multicolumn{2}{|r|}{$T T$} & & \\
\hline & $n$ & Statistic & $n$ & Statistic & $n$ & Statistic & None & Full \\
\hline SBP at home $(\mathrm{mmHg})$ & 347 & $125.6 \pm 0.8$ & 329 & $124.9 \pm 0.8$ & 61 & $128.2 \pm 1.8$ & 0.11 & 0.12 \\
\hline DBP at home $(\mathrm{mmHg})$ & 347 & $76.9 \pm 0.5$ & 329 & $76.5 \pm 0.5$ & 61 & $79.3 \pm 1.2$ & 0.08 & 0.05 \\
\hline Daytime SBP (mmHg) & 336 & $126.7 \pm 0.6$ & 320 & $125.7 \pm 0.6$ & 60 & $129.8 \pm 1.3$ & 0.009 & 0.009 \\
\hline Daytime DBP (mmHg) & 336 & $76.9 \pm 0.4$ & 320 & $76.6 \pm 0.4$ & 60 & $79.3 \pm 1.0$ & 0.04 & 0.02 \\
\hline Body weight $(\mathrm{kg})$ & 347 & $76.4 \pm 0.5$ & 329 & $77.3 \pm 0.5$ & 61 & $79.5 \pm 1.3$ & 0.06 & 0.04 \\
\hline Body mass index $\left(\mathrm{kg} / \mathrm{m}^{2}\right)$ & 347 & $25.3 \pm 0.2$ & 329 & $25.6 \pm 0.2$ & 61 & $26.3 \pm 0.4$ & 0.13 & 0.06 \\
\hline Triceps skinfold thickness (mm) & 285 & $12.2 \pm 0.4$ & 266 & $12.6 \pm 0.4$ & 52 & $14.7 \pm 0.8$ & 0.008 & 0.007 \\
\hline Erythrocyte count $\left(10^{12} / \mathrm{I}\right)$ & 339 & $4.90 \pm 0.02$ & 326 & $4.86 \pm 0.02$ & 61 & $4.99 \pm 0.05$ & 0.01 & 0.04 \\
\hline Haematocrit (\%) & 338 & $45.0 \pm 0.2$ & 326 & $44.7 \pm 0.2$ & 61 & $45.8 \pm 0.4$ & 0.009 & 0.02 \\
\hline Plasma insulin (mU/I) & 266 & $11.8(10.8-13.0)$ & 257 & $10.7(9.8-11.8)$ & 51 & $15.4(12.5-19.0)$ & 0.002 & 0.006 \\
\hline Insulin resistance ${ }^{\dagger}$ & 111 & $1.68(1.53-1.84)$ & 120 & $1.65(1.51-1.81)$ & 20 & $2.23(1.78-2.79)$ & 0.002 & 0.01 \\
\hline
\end{tabular}


Table 5 Adjusted phenotypes by G-protein $\beta_{3}$-subunit genotype in women

\begin{tabular}{|c|c|c|c|c|c|c|}
\hline \multirow[b]{3}{*}{ Characteristic } & \multicolumn{6}{|c|}{ Adjusted G-protein $\beta_{3}$-subunit genotypes* } \\
\hline & \multicolumn{2}{|r|}{$\mathrm{CC}$} & \multicolumn{2}{|r|}{$C T$} & \multicolumn{2}{|r|}{$T T$} \\
\hline & $n$ & Statistic & $n$ & Statistic & $n$ & Statistic \\
\hline SBP at home $(\mathrm{mmHg})$ & 368 & $120.3 \pm 0.7$ & 333 & $121.7 \pm 0.8$ & 74 & $120.3 \pm 1.6$ \\
\hline DBP at home $(\mathrm{mmHg})$ & 368 & $73.7 \pm 0.5$ & 333 & $74.6 \pm 0.5$ & 74 & $74.8 \pm 1.1$ \\
\hline Daytime SBP (mmHg) & 363 & $121.7 \pm 0.5$ & 318 & $122.4 \pm 0.6$ & 72 & $122.5 \pm 1.2$ \\
\hline Daytime DBP (mmHg) & 363 & $74.1 \pm 0.4$ & 318 & $75.4 \pm 0.4$ & 72 & $74.1 \pm 0.9$ \\
\hline Body weight $(\mathrm{kg})$ & 368 & $65.9 \pm 0.6$ & 333 & $65.2 \pm 0.7$ & 74 & $66.0 \pm 1.4$ \\
\hline Body mass index $\left(\mathrm{kg} / \mathrm{m}^{2}\right)$ & 368 & $25.3 \pm 0.2$ & 333 & $25.1 \pm 0.3$ & 74 & $25.4 \pm 0.5$ \\
\hline Triceps skinfold thickness (mm) & 291 & $2.14 \pm 0.04$ & 262 & $2.18 \pm 0.04$ & 62 & $2.09 \pm 0.09$ \\
\hline Erythrocyte count $\left(10^{12} / \mathrm{l}\right)$ & 357 & $4.40 \pm 0.02$ & 329 & $4.48 \pm 0.02$ & 74 & $4.51 \pm 0.04$ \\
\hline Haematocrit (\%) & 357 & $40.6 \pm 0.2$ & 329 & $41.2 \pm 0.2$ & 74 & $41.2 \pm 0.4$ \\
\hline Plasma insulin (mU/l) & 276 & $11.9(10.9-13.0)$ & 250 & $12.1(11.0-13.3)$ & 58 & $11.8(9.8-14.4)$ \\
\hline Insulin resistance & 124 & $1.64(1.51-1.79)$ & 111 & $1.63(1.49-1.79)$ & 26 & $1.64(1.35-1.98)$ \\
\hline
\end{tabular}

SBP, systolic blood pressure; DBP, diastolic blood pressure. Values are arithmetic means (standard error) or geometric means (95\% confidence interval) adjusted for the co-variables presented in Table 3. * Before and after adjustment for the co-variables presented in Table 3, $P$ values for differences across genotypes were non-significant with the exception of erythrocyte count $(P<0.001)$ and haematocrit $(P=0.03)$

sets of co-variables as mentioned earlier using generalized estimating equations instead of analysis of covariance to allow for the non-independence of the observations within families. Again, these analyses confirmed our results.

\section{Discussion}

Our epidemiological study tested 'a priori' hypotheses concerning pre-defined phenotype-genotype associations. However, it was neither designed to disentangle complex pathophysiological mechanisms nor to prove causality. Nevertheless, our observations suggest a new working hypothesis concerning the association between hypertension and the C825T polymorphism. First, the mutated $825 T$ allele may increase blood pressure through a metabolic pathway characterized by the presence of obesity and insulin resistance [6]. Second, the higher haematocrit and erythrocyte count associated with the splice variant may raise blood pressure, because they increase blood viscosity and resistance to arteriolar blood flow [17] or because they increase oxygen delivery to peripheral tissues, thereby leading to arterial vasoconstriction [18].

Studies of possible association between various cardiovascular phenotypes and the C825T polymorphism of the G-protein $\beta_{3}$-subunit gene produced inconsistent results. The mutated $825 T$ allele was associated with higher blood pressure [7-9,19] or increased risk of hypertension [2,8,20,21] in Germans [2,7,9,20], Australian white hypertensive patients [19], and Caribbean or West African blacks [21], but not in French [8], Irish [8], Japanese [22,23], or African-Americans [24]. Few of the aforementioned studies reported analyses stratified by gender $[9,19]$. Only one smaller study in Canadian Oji-Cree noticed significantly lower systolic and diastolic blood pressures in TT homozygotes than in $C$ allele carriers [25]. Among hypertensive patients, left ventri- cular hypertrophy [26] or impaired left ventricular diastolic filling [27] were linked with the mutated Gprotein $\beta_{3}$-subunit allele in Spanish [26] and in Germans [27]. These discordant cardiovascular findings suggest that ethnic and genetic background [4], lifestyle and various environmental factors may modulate the small effect of the C825T allele on blood pressure. The frequency of the $T$ allele was 0.31 in our Caucasian population, but approximately 0.50 in Japanese [22,23] or native Americans [25,28], and 0.75 in blacks [21,24]. Another reason for the divergent findings with regard to blood pressure may reside in the fact that this phenotype is more distant from the C825T genetic polymorphism than the intermediate haematological and metabolic factors, which may contribute to the rise in blood pressure, but for which many counter-regulatory mechanisms may compensate.

We observed thickening of the triceps skinfold, slightly higher body mass index and body weight and higher risk of obesity in $T T$ homozygous men. Increased signalling by pertussis-toxin-sensitive G-proteins stimulates adipogenesis [3]. Published reports on the association between measures of obesity [4] and the G-protein $\beta_{3}$-subunit $6825 T$ polymorphism are more consistent than those on hypertension. Several studies [4] demonstrated that the $825 T$ homozygous genotype was positively associated with obesity or higher body mass index in blacks, Caucasians and Chinese. Primiparous $T T$ homozygotes are at increased risk of obesity and post-pregnancy obesity [29]. Siffert speculated that the $825 T$ allele predisposes to obesity and hypertension via hyperinsulinaemia [6]. In line with this hypothesis, we found higher plasma insulin concentrations and more insulin resistance in TT homozygous men.

To the best of our knowledge, we are the first to report slight increases in haematocrit and erythrocyte count in 
association with the $G$-protein $\beta_{3}$-subunit $825 T$ allele. Long-term increase in haematocrit leads to vasoconstriction-dependent hypertension, which is characterized by elevated cytoplasmic calcium concentration in vascular smooth muscle cells and by resistance to the vasodilatory action of nitric oxide [18]. Erythropoietin is the major regulator of the proliferation and differentiation of erythroid progenitor cells. Promotion of cell growth by erythropoietin [30,31] is primarily mediated via activation of the JAK/STAT pathway involving a specific set of cytosolic tyrosine kinases (JAKs) and transcription factors (STATs), and via stimulation of various protein kinase $\mathrm{C}$ isoforms. However, molecular studies also produced evidence for the involvement of heterotrimeric G-proteins in erythropoiesis [31-35]. $G_{i}{ }^{-}$ proteins are associated with the C-terminal end of the erythropoietin receptor [32]. Activation of this receptor leads to dissociation of the $\mathrm{G}_{i}$-protein, suggesting a functional role of the $\mathrm{G}_{i}$-protein in signal transduction [32]. Upon stimulation of the erythropoietin receptor, G-proteins mediate a dose-dependent increase in cytosolic calcium via voltage-independent calcium channels [33]. Moreover, in human erythroid progenitor cells, Gproteins inhibit the antiproliferative effects of the activated thrombin receptor $[31,34,35]$. Thus, although the exact molecular pathways still need further clarification, experimental evidence supports the concept that the G-protein $\beta_{3}$-subunit $C 825 T$ polymorphism may be associated with significant, albeit small, changes in erythropoiesis [31-35].

Adjustment for body mass index, haematocrit or both factors did not completely remove the effect of the C825T polymorphism on the daytime ambulatory blood pressure in men. Mechanisms other than those proposed might therefore also play a role. At the kidney level, stimulation of the $\mathrm{Na}^{+} / \mathrm{H}^{+}$exchanger may increase $\mathrm{Na}^{+}$re-absorption and cause chronic volume expansion with a compensatory inhibition of plasma renin activity [6]. In keeping with this hypothesis [6], one population-based study [7] reported a significantly lower plasma renin activity in the presence of the $T$ allele. Furthermore, Turner and colleagues [36] observed in patients with essential hypertension that systolic and diastolic blood pressures declined 5-6 $\mathrm{mmHg}$ more in response to diuretic treatment in $T T$ homozygotes than in $C G$ homozygotes. Zeltner and associates [5] found in young men with normotension or mild incipient essential hypertension that carriers of the $825 T$ allele had a faster tubular sodium re-absorption than $C G$ homozygotes. Although we did not observe a significant decrease in plasma renin activity in $T$ allele carriers, our study does not exclude chronic sodium retention $[5,6]$ as a pathway underlying the higher blood pressure in TT homozygous men. Other possible mechanisms involve altered intracellular signalling after $\alpha$-adrenergic or $\beta$-adrenergic receptor sti- mulation [1]. Current knowledge does not allow one to differentiate between the involvement of distinct Gprotein subunits and their isoforms in pathophysiological processes, but the $\beta_{3}$-subunit is widely distributed across most tissues.

Before we engaged in the statistical analysis, we planned to analyse men and women separately. Indeed, blood pressure is an age-related trait with a genderspecific time course during life. Syndrome $\mathrm{X}$ is more prevalent among men than women [37]. Furthermore, several studies involving other known candidate genes revealed gender-specific associations with blood pressure. For instance, in two large-scale population studies $[38,39]$, the risk of hypertension was related to the deletion polymorphism of the angiotensin-converting enzyme in men, but not in women. We previously found that, in our Flemish population, $C G$ homozygosity at position 1797 of the $\beta$-adducin gene was associated with a lower risk of hypertension in women, but not in men [40].

Our sample size was sufficiently large to accommodate sex-specific analyses [16]. The biological consistency among men in the direction of the phenotypic changes associated with the TT genotype may be due to the intrinsic features of the metabolic syndrome [37]. On the other hand, the coherence and plausibility of the latter results can also be interpreted as evidence arguing against a type-1 error due to chance. Conversely, our null findings in women with regard to blood pressure and obesity might be due to a type II error. However, sample size calculations performed by Trégouët and colleagues [16] demonstrated that 650 unrelated subjects are sufficient to detect, with $90 \%$ power, an association with an allele, which has a frequency of $30 \%$ and explains $1.6 \%$ of the variance of a continuous phenotype. In similarly informed calculations involving either families with two offspring or mixed populations consisting of related and unrelated people, 650 subjects still provided $85-88 \%$ power, regardless of whether the analysis accounted for family structure. Sexual dimorphism exists in the heritability of blood pressure [41]. It is, therefore, conceivable that our null findings in women are due to a modification of the genetic effect, for instance by female sex hormones. Oestradiol increases inositol triphosphate formation via a signalling process that is linked to a pertussis-toxinsensitive G-protein [42]. Moreover, oestradiol acutely and chronically behaves as a vasodilator [43].

Our findings did not evolve from a post-hoc hypothesis, neither in terms of the selected phenotype-genotype associations nor in terms of the separate analysis of men and women. Nevertheless, our results must be interpreted within the context of their limitations. They hinged on the differences between male $C$ allele 
carriers and TT homozygotes. Among men, the frequency of the $T T$ genotype amounted to $8.3 \%$. Only 20 TT homozygous men were available for the study of insulin sensitivity. Furthermore, with adjustments for co-variables applied, the increases in diastolic blood pressure, body weight, erythrocyte count and haematocrit in TT homozygous men were only borderline significant. $P$ values are key in guiding statistical inference, but should also be interpreted within the context of pathophysiological plausibility [44]. With these limitations in mind, our findings should be viewed as hypothesis-generating and require further confirmation in sufficiently powered epidemiological studies, especially in populations with a higher prevalence of the $T$ allele [4].

In conclusion, male and female carriers of the $T$ allele at position 825 of the $G$-protein $\beta_{3}$-subunit gene have a slightly higher haematocrit and erythrocyte count. Male TT homozygotes have a higher blood pressure and are more obese and insulin-resistant than their $C$ allele counterparts. We speculated that increased G-proteinmediated signalling upon stimulation of the erythropoietin or thrombin receptor of erythroid progenitor cells might explain the higher haematocrit and erythrocyte count associated with the $T$ allele. Furthermore, the higher blood pressure in TT homozygous men might be brought about via a metabolic pathway characterized by obesity and insulin resistance as well as via increased peripheral arterial resistance secondary to the higher haematocrit.

\section{Acknowledgements}

The FLEMENGHO study would not have been possible without the collaboration of the family physicians of the participants. The municipality HechtelEksel (Belgium) provided logistic support. The authors acknowledge the expert assistance of Rina Bollen, Lut De Pauw, Elly Den Hond, Paul Drent, Jerzy Gąsowski, Heng Fan, Lieve Gijsbers, Alida Hermans, Tatyana Kuznetsova, Tim Nawrot, Katarzyna Stolarz, Lutgarde Thijs, Valérie Tikhonoff, Yvette Toremans, Sylvia Van Hulle and Renilde Wolfs (Study Coordinating Centre, Leuven, Belgium). Brigitte Egbers (Berlin, Germany) helped in genotyping.

\section{References}

1 Farfel Z, Bourne HR, liri T. The expanding spectrum of $\mathrm{G}$ protein diseases. N Engl J Med 1999; 340:1012-1020.

2 Siffert W, Rosskopf D, Siffert G, Busch S, Moritz A, Erbel R, et al. Association of a human G-protein $\beta 3$ subunit variant with hypertension. Nat Genet 1998; 18:45-48.

3 Su HL, Malbon CC, Wang HY. Increased expression of $G_{i}$ alpha 2 in mouse embryo stem cells promotes terminal differentiation to adipocytes. Am J Physiol 1993; 265:C1729-C1735.

4 Siffert W, Forster P, Jöckel KH, Mvere DA, Brinkmann B, Naber C, et al. Worldwide ethnic distribution of the $G$ protein $\beta 3$ subunit $825 \mathrm{~T}$ allele and its association with obesity in Caucasians, Chinese, and black African individuals. J Am Soc Nephrol 2001; 10:1921-1930.

5 Zeltner R, Delles C, Schneider M, Siffert W, Schmieder RE. G-Protein $\beta_{3}$ subunit gene (GNB3) $825 T$ allele is associated with enhanced renal perfusion in early hypertension. Hypertension $2001 ; 37: 882-886$.

6 Siffert W. G protein $\beta 3$ subunit 825 T allele, hypertension, obesity, and diabetic nephropathy. Nephrol Dial Transplant 2000; 15:1298-1306.

7 Schunkert H, Hense HW, Döring A, Riegger GAJ, Siffert W. Association between a polymorphism in the $\mathrm{G}$ protein $\beta 3$ subunit gene and lower renin and elevated diastolic blood pressure levels. Hypertension 1998; 32:510-513.

8 Brand E, Herrmann SM, Nicaud V, Ruidavets JB, Evans A, Arveiler D, et al. The $825 \mathrm{C} / \mathrm{T}$ polymorphism of the G-protein subunit $\beta 3$ is not related to hypertension. Hypertension 1999; 33:1175-1178.

9 Hengstenberg C, Schunkert H, Mayer B, Döring A, Löwel H, Hense HW, et al. Association between a polymorphism in the $\mathrm{G}$ protein $\beta 3$ subunit gene (GNB3) with arterial hypertension but not with myocardial infarction. Cardiovasc Res 2001; 49:820-827.

10 Cruickshank JK, Mbanya JC, Wilks R, Balkau B, McFarlane-Anderson N, Forrester T. Sick genes, sick individuals or sick populations with chronic disease? The emergence of diabetes and high blood pressure in Africanorigin populations. Int J Epidemiol 2001; 30:111-117.

11 Staessen JA, Wang JG, Brand E, Barlassina C, Birkenhäger WH, Herrmann SM, et al. Effects of three candidate genes on prevalence and incidence of hypertension in a Caucasian population. $J$ Hypertens 2001; 19:1349-1358.

12 Matthews DR, Hosker JP, Rudenski AS, Naylor BA, Treacher DF, Turner RC. Homeostasis model assessment: insulin resistance and b-cell function from fasting glucose and insulin concentrations in man. Diabetologia 1985; 28:412-419.

13 Levine MA, Smallwood PM, Moen PT Jr, Helman LJ, Ahn TG. Molecular cloning of beta 3 subunit, a third form of the $\mathrm{G}$ protein beta-subunit polypeptide. Proc Natl Acad Sci USA 1990; 87:2329-2333.

14 Hosmer DW Jr, Lemeshow S. Interpretation of coefficients. In: Applied logistic regression. New York: John Wiley \& Sons; 1989. pp. 38-81.

15 Zeger SL, Liang KY, Albert PS. Models for longitudinal data: a generalized estimating equation approach. Biometrics 1988; 44:1049-1060.

16 Trégouët DA, Ducimetière $P$, Tiret $L$. Testing associations between candidate-gene markers and phenotype in related individuals by use of estimating equations. Am J Hum Genet 1997; 61:189-199.

17 Raine AEG. Hypertension, blood viscosity, and cardiovascular morbidity in renal failure. Implications of erythropoietin therapy. Lancet 1988; i: 97-100.

18 Vaziri ND. Cardiovascular effects of erythropoietin and anemia correction. Curr Opin Nephrol Hypertens 2001; 10:633-637.

19 Benjafield AV, Jeyasingam CL, Nyholt DR, Griffiths LR, Morris BJ. G-protein $\beta 3$ subunit gene (GNB3) variant in causation of essentia hypertension. Hypertension 1998; 32:1094-1097.

20 Beige J, Hohenbleicher H, Distler A, Sharma AM. G-protein $\beta 3$ subunit C825T variant and ambulatory blood pressure in essential hypertension. Hypertension 1999; 33:1049-1051.

21 Dong Y, Zhu H, Sagnella GA, Carter ND, Cook DG, Cappuccio FP. Association between the C825T polymorphism of the $G$ protein $\beta 3$ subunit gene and hypertension in blacks. Hypertension 1999; 34: 1193-1196.

22 Kato N, Sugiyama T, Morita H, Kurihara H, Yamori Y, Yazaki Y. G protein $\beta 3$ subunit variant and essential hypertension in Japanese. Hypertension 1998; 32:935-938

23 Ishikawa K, Imai Y, Katsuya T, Ohkubo T, Tsuji I, Nagai K, et al. Human $\mathrm{G}$-protein $\beta 3$ subunit variant is associated with serum potassium and total cholesterol levels but not with blood pressure. Am J Hypertens 2000; 13:140-145.

24 Larson N, Hutchinson R, Boerwinkle E. Lack of association of 3 functional gene variants with hypertension in African Americans. Hypertension 2000; 35:1297-1300.

25 Hegele RA, Harris SB, Hanley AJG, Cao H, Zinman B. G Protein $\beta 3$ subunit gene variant and blood pressure variation in Canadian Oji-Cree. Hypertension 1998; 32:688-692.

26 Poch E, Gonzáles D, Gómez-Angelats E, Enjuto M, Paré JC, Riera F, et al. G-protein $\beta_{3}$ subunit gene variant and left ventricular hypertrophy in essential hypertension. Hypertension 2000; 35(part 2):214-218.

27 Jacobi J, Hilgers KF, Schlaich MP, Sifffert W, Schmieder RE. 825T allele of the G-protein $\beta_{3}$ subunit gene (GNB3) is associated with impaired left ventricular diastolic filling in essential hypertension. J Hypertens 1999; 17:1457-1462.

28 Hegele RA, Anderson C, Young TK, Connelly PW. G-protein $\beta 3$ subunit gene splice variant and body fat distribution in Nunavut Inuit. Genome Res 1999; 9:972-977.

29 Gutersohn A, Naber C, Müller N, Erbel R, Siffert W. G protein $\beta 3$ subunit $825 T T$ genotype and post-pregnancy weight retention. Lancet 2000; 355:1240-1241. 
30 Kashii Y, Uchida M, Kirito K, Tanaka M, Nishijima M, Ando T, et al. A member of Forkhead family transcription factor, FKHRL1, is one of the downstream molecules of phosphatidylinositol 3-kinase-Akt activation pathway in erythropoietin signal transduction. Blood 2000; 96:941-949.

31 Haslauer M, Baltensperger K, Porzig $\mathrm{H}$. Erythropoietin- and stem cell factor-induced DNA synthesis in normal human erythroid progenitor cells requires activation of protein kinase $\mathrm{C} \alpha$ and is strongly inhibited by thrombin. Blood 1999; 94:114-126.

32 Guillard C, Chrétien S, Jockers R, Fichelson S, Mayeux P, Duprez V. Coupling of heterotrimeric $\mathrm{G}_{\mathrm{i}}$ proteins to the erythropoietin receptor. J Biol Chem 2001; 276:2007-2014.

33 Miller BA, Bell L, Hansen CA, Robishaw JD, Linder ME, Cheung JY. G-protein $\alpha$ subunit $\mathrm{G}_{i} \alpha_{2}$ mediates erythropoietin signal transduction in human erythroid precursors. J Clin Invest 1996; 98:1728-1736.

34 Kesselring F, Spicher K, Porzig H. Changes in G protein pattern and in G protein-dependent signaling during erythopoietin- and dimethylsulfoxideinduced differentiation of murine erythroleukemia cells. Blood 1994; 84:4088-4098.

35 Clejan S, Mallia C, Vinson D, Dotson R, Beckman BS. Erythropoietin stimulates G-protein-coupled phospholipase $D$ in haematopoietic target cells. Biochem J 1996; 314:853-860.

36 Turner ST, Schwartz GL, Chapman AB, Boerwinkle E. C825T polymorphism of the $\mathrm{G}$ protein $\beta 3$-subunit and antihypertensive response to a thiazide diuretic. Hypertension 2001; 37(part 2):739-743.

37 Strazzullo P, Barba G, Cappuccio P, Siani A, Trevisan M, Farinaro E, et al. Altered renal sodium handling in men with abdominal adiposity: a link to hypertension. J Hypertens 2001; 19:2157-2164.

38 O'Donnell CJ, Lindpaintner K, Larson MG, Rao VS, Ordovas JM, Schaefer $E J$, et al. Evidence for association and genetic linkage of the angiotensinconverting enzyme locus with hypertension and blood pressure in men but not women in the Framingham Heart Study. Circulation 1998; 97:1766-1772.

39 Higaki J, Baba S, Katsuya T, Sato N, Ishikawa K, Mannami T, et al. Deletion allele of angiotensin-converting enzyme gene increases risk of essential hypertension in Japanese men. The Suita Study. Circulation 2000; 101:2060-2065.

40 Wang JG, Staessen JA, Barlassina C, Fagard R, Kuznetsova T, Struijker Boudier $\mathrm{HA}$, et al. Association between hypertension and variation in the $\alpha$ - and $\beta$-adducin genes in a white population. Kidney Int 2002; 62:2152-2159.

41 Jamerson KA, Schork N, Julius S. Effect of home pressure and gender on estimates of the familial aggregation of blood pressure. The Tecumseh Blood Pressure Study. Hypertension 1992; 20:314-318.

42 Le Mellay V, Lasmoles F, Lieberherr M. Galpha(q/11) and gbetagamma proteins and membrane signalling of calcitriol and estradiol. $J$ Cell Biochem 1999; 75:138-146.

43 Oparil S. Hormones and vasoprotection. Hypertension 1999; 33(part 2): 170-176.

44 Goodman SN. Towards evidence-based medical statistics. 1: the $P$ value fallacy. Ann Intern Med 2000; 130:995-1004. 